\title{
TECTONO-SEDIMENTARY STRUCTURE AND LATE QUATERNARY EVOLUTION OF THE NORTH EVIA GULF BASIN, CENTRAL GREECE: PRELIMINARY RESULTS
}

\author{
Sakellariou D. ${ }^{1}$, Rousakis G. ${ }^{1}$, Kaberi H. ${ }^{1}$, Kapsimalis V. ${ }^{1}$, Georgiou P. ${ }^{1}$, \\ Kanellopoulos Th. ${ }^{1}$, and Lykousis V. ${ }^{1}$ \\ ${ }^{\prime}$ Institute of Oceanography, Hellenic Centre for Marine Research, Anavyssos, Greece, \\ sakell@ath.hcmr.gr,rousakis@ath.hcmr.gr,ekaberi@ath.hcmr.gr,kapsim@ath.hcmr.gr, \\ pgeorg@ath.hcmr.gr,thkan@ath.hcmr.gr,vlikou@ath.hcmr.gr
}

\begin{abstract}
Systematic single channel seismic and $3.5 \mathrm{kHz}$ profiling, gravity and box coring and ${ }^{210} \mathrm{~Pb}$ downcore analyses shed light to the structure and the Late Quaternary evolution of the North Evia Gulf graben. The latter is segmented along its axis in three distinct basins. The shallow, E-W striking western basin displays southward asymmetry. The NW-SE striking, deep central basin and the shallow southeastern one show NE-ward asymmetry and are controlled by the Aidipsos, Telethrion and Kandili fault zones. Sequence stratigraphic data and aragonite crystals in mud layers underlying Holocene deposits verifies that North Evia Gulf was a lake during the last glacial maximum with lake level at about $90 \mathrm{~m}$ below the present sea level.

Key words: basin segmentation, tectonic asymmetry, active faulting, lake level.
\end{abstract}

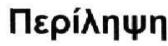

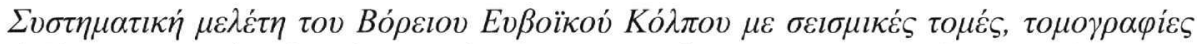

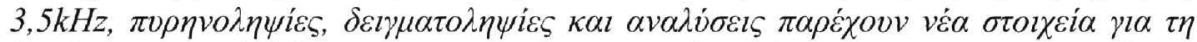

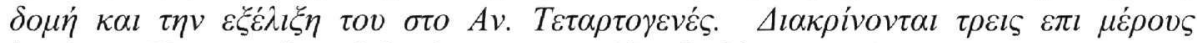

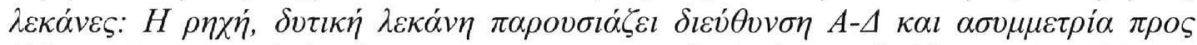

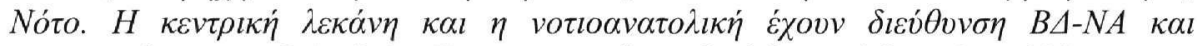

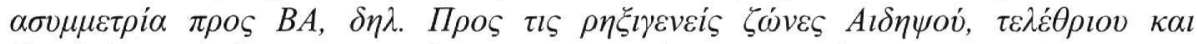

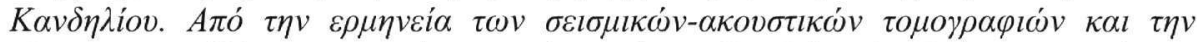

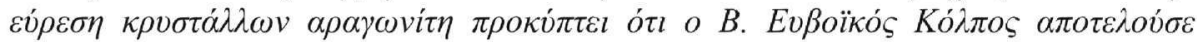

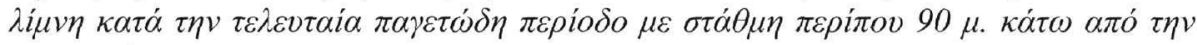
$\sigma \eta \mu \varepsilon \rho v \dot{\eta}$.

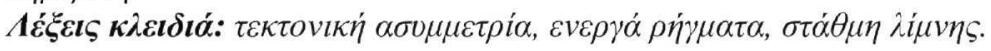

\section{Introduction}

The aim of this paper is to explore the neotectonic architecture and the sedimentary fill of the North Evia Gulf active basin and to contribute to the understanding of the deformation and seismic hazard of the area. Furthermore, we present new data on the sea/lake level changes in the Latest Quaternary. 
The North Evia Gulf is one of the active rifts/basins, together with the Gulf of Corinth, the Gulf of Patras and other onshore located basins, which overtake the crustal strain in Central Greece region, between the southwestern tip of the North Anatolian Fault and the northeastern tip of the Kefallinia Fault. According to Roberts and Jackson (1991) the area of Central Greece, between Northern Peloponese and Northern Evia has undergone total extension of 20-30 km in NNE-SSW direction and is being presently deformed by a rate of $1 \mathrm{~cm} / \mathrm{yr}$ (Davies et al. 1997). Although a considerable part of this extension may take place in the Gulf of Corinth area (Billiris et al. 1991, Armijo et al. 1996, Clarke et al. 1997), the thinned, only $20 \mathrm{~km}$ in thickness, crust below the central North Evia Gulf (Makris et al. 2001) is a strong evidence of significant extension too.

The most recent strong earthquake activity dates back to April 1894, when during the Atalanti earthquake sequence the homonymous fault was broken for more than $30 \mathrm{~km}$ and was followed by tsunami waves, which flooded the low coastal plains of Atalanti Gulf (Pantosti et al. 2001, Skouphos 1894, Philippson 1894, Mitsopoulos 1895, Richter 1958, Lemeille 1977, Rondoyianni 1984, Ambraseys and Jackson 1990, Ganas et al. 1997).

Despite the surficial sediment map, published by IGME in 1991, few studies of the submarine structure of the North Evia Gulf have been conducted (Van Andel and Perissoratis 2006). Herewith we present results of a systematic survey of the neotectonic basin, conducted in years 2004-2006.

\section{Materials and Methods}

The marine geological survey in the N. Evia Gulf took place in 2004 . A total of $700 \mathrm{~km}$ singlechannel seismic profiles (Fig. 1a) were acquired using an Air Gun, $10 \mathrm{in}^{3}$ air chamber (Bolt USA) simultaneously with a 4-transducer ORE $3.5 \mathrm{kHz}$ sub-bottom profiler. Seismic profiling data were acquired both in analog form on an EPC recorder and digitally using Delph Seismic + software, geo-encoded using Delph Map v. 2.9.6 software and post-processed using SeismicGIS software of Triton Imaging Inc. For the swath bathymetric survey of the gulf a SEABEAM $2120(20 \mathrm{kHz})$ system was used (Alexandri et al. 2005). Twenty eight gravity cores (using a BENTHOS INS gravity corer) and ten box cores (Fig. 1a) were collected, described macroscopically and analyzed under a Multi Sensor Core Logger for their petro-physical characteristics. Selected samples from the cores were imaged under the scanning-electron-microscope. Actual sedimentation rates (late $0.1 \mathrm{ka}$ ) were determined in undisturbed sub-cores from two box cores using the ${ }^{210} \mathrm{~Pb}$ method (Appleby and Oldfield 1992, Sanchez-Cabeza et al. 1998, Radakovitch 1995).

\section{Basin architecture}

\subsection{Along-axis segmentation}

Morphologically and, as it will be shown hereafter, geologically the North Evia Gulf graben can be subdivided along axis into three distinct basins: the western, the central and the southeastern basin (Fig. 1b). The first and the third one are flat bottomed with maximum depth not exceeding $100 \mathrm{~m}$. The central basin is the deepest one, with maximum depth of about $440 \mathrm{~m}$. The boundaries between the three basins are marked by moderately steep slopes along the lines Aidipsos-Arkitsa and Limni-Malesina Peninsula. The Aidipsos-Arkitsa boundary marks the change of the basin's strike from E-W $\left(\mathrm{N} 90^{\circ} \mathrm{E}\right)$ in the western basin to NW-SE $\left(\mathrm{N} 120^{\circ} \mathrm{E}\right)$ in the central and southeastern basins. The steepest slopes in North Evia Gulf occur off North Evia coasts, between Aidipsos and Limni, and form the northeastern margin of the central basin.

\subsection{Western Basin}

The E-W trending western basin extends from the volcanic Lichadhes islands to the west to the Arkitsa-Aidipsos flexure to the east and constitutes the eastward prolongation of Sperchios valley. On the southern coasts, the Kamena Vourla, Agios Konstantinos and Arkitsa-Logos fault zones 


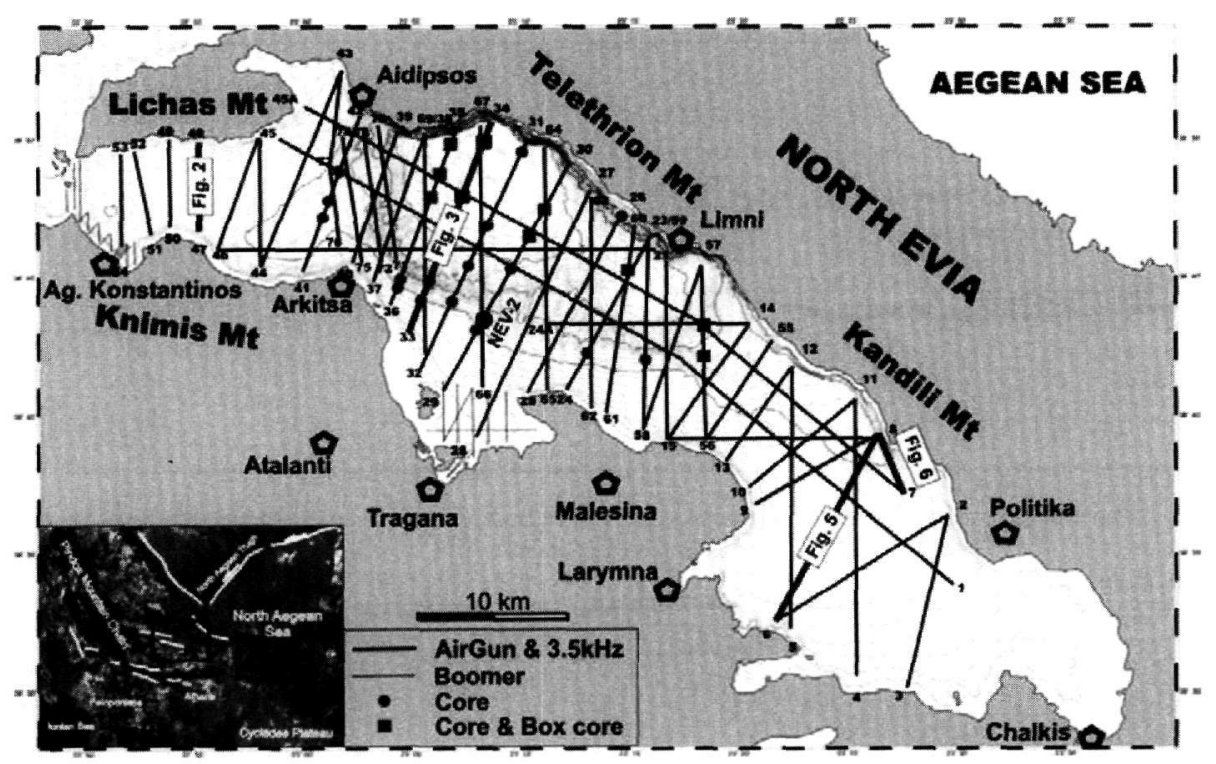

Figure 1a - Location map of AirGun $10 \mathrm{in}^{3}$ profiles, $3.5 \mathrm{kHz}$ profiles, gravity cores and box cores in the North Evia Gulf. Seismic profiles and gravity/box coring sites presented in this paper are marked on the map. NEV-12 and NEV-13 box cores presented in Fig. 4 are shown as black squares. Inset map shows main tectonic lines in Central Greece

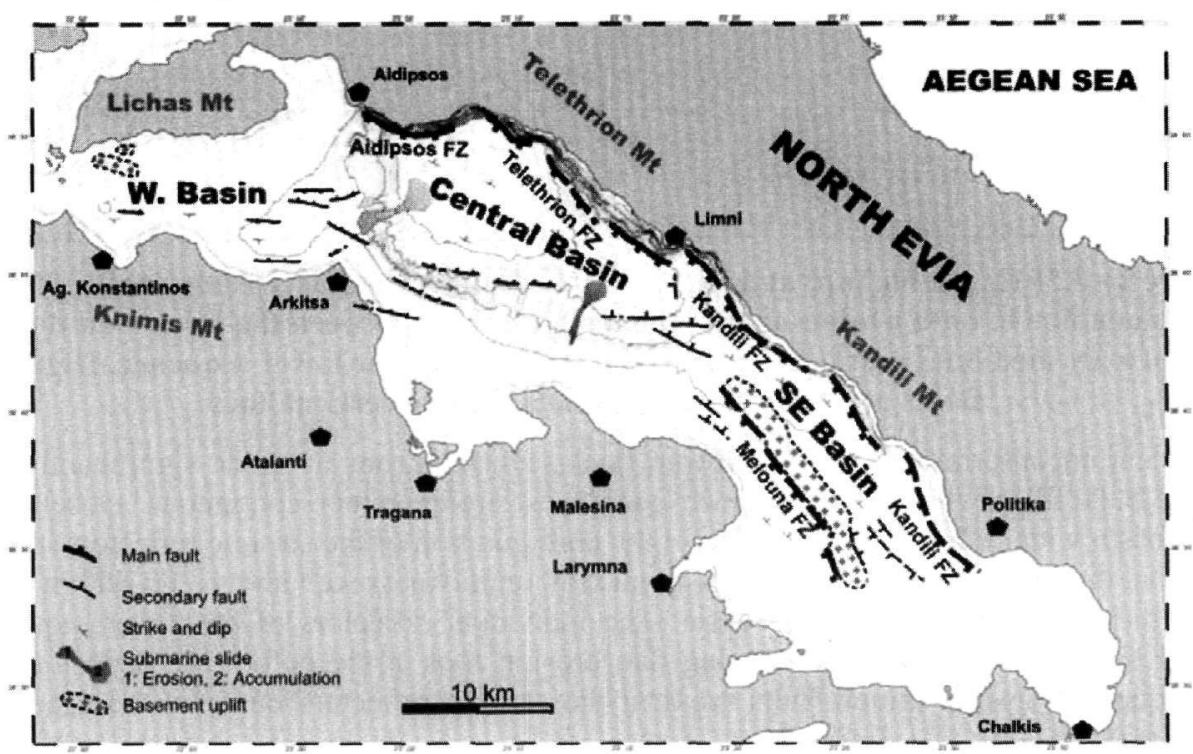

Figure 1 b - Tectonic map of North Evia Gulf. Bathymetry from Alexandri et al. (2005). The main fault zones are marked as thick black lines. The three, structurally differentiated, basins of the North Evia Gulf are also indicated on the map

(Kranis 1999) form the tectonic boundary between the uplifting alpine basement of Knimis Mt. and the basin. No other marginal fault was imaged on the seismic profiles (Fig. 2) from the western basin, along either the southern or the northern margin. 

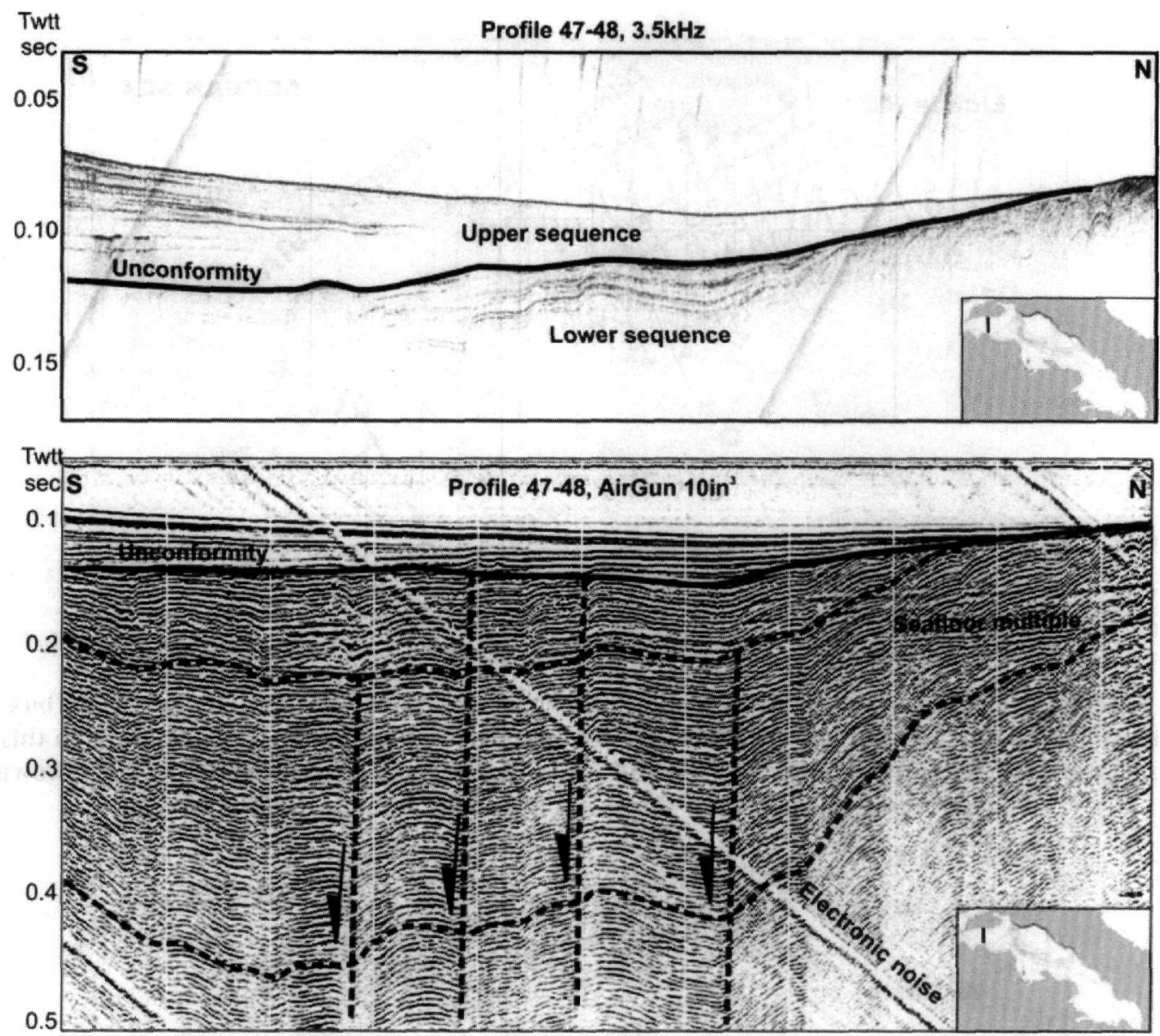

Figure 2 - 3.5kHz profile (up) and Air Gun $10 \mathrm{in}^{3}$ single channel seismic profile (down). Thick black line in both profiles marks the unconformity between the lower and the upper sequence. Dashed lines mark the trace of the reflectors of the lower sequence. High angle faults are also shown as dashed, nearly vertical lines

A prominent unconformity separates a lower, thick sequence from an upper, significantly thinner, one. The bulk fill of the lower sequence comprises strong, rather continuous, closely spaced, parallel, basin wide reflectors (Fig. 2). From the configuration of the seismic reflectors it becomes evident that the depocenter of the basin, with maximum thickness well above $300-400 \mathrm{~m}$, lies very close to the southern margin of the basin. The individual reflectors of the lower sequence are truncated by the unconformity, indicating that erosion took place before the deposition of the upper sequence. Several minor faults crosscut the seismic reflectors but they are caped by the unconformity.

The upper sequence displays transparent acoustic character, with wider spaced continuous reflectors, which onlap the underlying unconformity (Fig. 2). Its maximum thickness does not exceed $30-40 \mathrm{~m}$ at the southern part of the basin and diminishes towards north. Although no age constrains are available, in analogy with other enclosed areas, like the Gulf of Corinth (Lykousis et al. 2006) and the Amvrakikos Gulf (Kapsimalis et al. 2005), and on the basis of the acoustic character and the underlying unconformity, we interpret the upper sequence as Holocene marine deposited sediments (see also Van Andel and Perissoratis 2006), derived mainly from the fertile material carried by the torrents, which drain the Knimis Mt. Small outcrops of acoustically opaque 
basement at the northwestern edge of the basin may represent volcanic rocks similar to the ones of Lichadhes islands.

\subsection{Central Basin}

The transition from the shallow, western basin to the deep, central one is marked by a moderately steep slope along the Aidipsos-Arkitsa line, which coincides with a flexure of the deposited sedimentary sequences below it, associated with a series of parallel, N-S trending, minor faults.

Similar configuration is observed along the southern slope of the basin (Fig. 3). The seismic reflectors below the southern shelf and slope dip south- or southwest-wards. The dip direction changes to northeast-wards immediately north of the southern, north-facing faults and remains so throughout the deep basin. The seismic stratigraphy of the basin implies continuous, strong reflectors fanning northwards, indicating thus enhanced subsidence close to the northern margin. The latter is marked by a steep slope and the presence of a large, basin-bounding fault zone, which includes the E-W trending Aidipsos fault and the NW-SE trending Telethrion fault (Figs 1b, 3). Large masses with chaotic acoustic character at the immediate vicinity of the fault surface indicate extensive, gravity-driven deposits, derived from the upper part of the northern slope (Fig. 3). Mass flow deposits occur also along the foot of the southern slope (Fig. 1b).

The overall structure of the central basin is the one of an asymmetric graben with the northeastern tectonic margin being the one which drives the subsidence of the basin throughout its evolution. The northeast-ward fanning configuration of the basin fill supports this interpretation and indicates higher sedimentation rates close to the northern margin. The two main fault zones, Arkitsa and Telethrion, which form the northeastern tectonic boundary of the central basin, have accommodated a cumulative throw well above $1000 \mathrm{~m}$.

Estimation of the actual sedimentation rates, from the ${ }^{210} \mathrm{~Pb}$ vertical distribution in very recent sediments from the deep central basin, shows similar pattern. The box cores NEV-12 and Nev-13 were taken from the deep central basin, the latter closer to the northern margin and are composed of mud. Their location is shown on the profile of Fig. 3.

The upper part of box core NEV-12, between $0-7 \mathrm{~cm}$ bsf. shows strong bioturbation and is thus not taken into consideration for the estimation of the accumulation rate. The supported ${ }^{210} \mathrm{~Pb}$ total activity was reached at $30 \mathrm{~cm}$ bsf. (Fig. 4). The maximum accumulation rate in box core NEV-12 was estimated from the ${ }^{210} \mathrm{~Pb}$ profile between $7-30 \mathrm{~cm}$ bsf, following the CRS model and was found $0.26 \mathrm{~cm} / \mathrm{y}$ for the last $100-120$ years. The upper $6 \mathrm{~cm}$ of box core NEV-13 (Fig. 4) are also bioturbated and were not taken into consideration, while the supported ${ }^{210} \mathrm{~Pb}$ total activity was reached at $30 \mathrm{~cm}$ bsf. Consequently, following CRS model and the different shape of the ${ }^{210} \mathrm{~Pb}$ profile, the maximum accumulation rate for the last 100-120 years was found $0.33 \mathrm{~cm} / \mathrm{y}$. This pattern is in accordance with the relative sedimentation rates below the sites of NEV-12 and NEV13 box cores, as they can be deduced from the geological data of the profile of Fig. 3 and the northeastward thickening of the individual reflectors. A very similar pattern has been observed in box cores taken across the asymmetric Alkyonides basin (Kaberi and Sakellariou 2006).

\subsection{Southeastern Basin}

A gradual morphological transition and a significant narrowing of the actual basin mark the transition from the central deep basin to the southeastern, shallow and flat basin. The latter displays very different geological structure and basin stratigraphy. A major fault zone, the Melouna one, striking parallel to the long axis and in the middle of the basin, divides it into two parallel, longitudinal subbasins. 


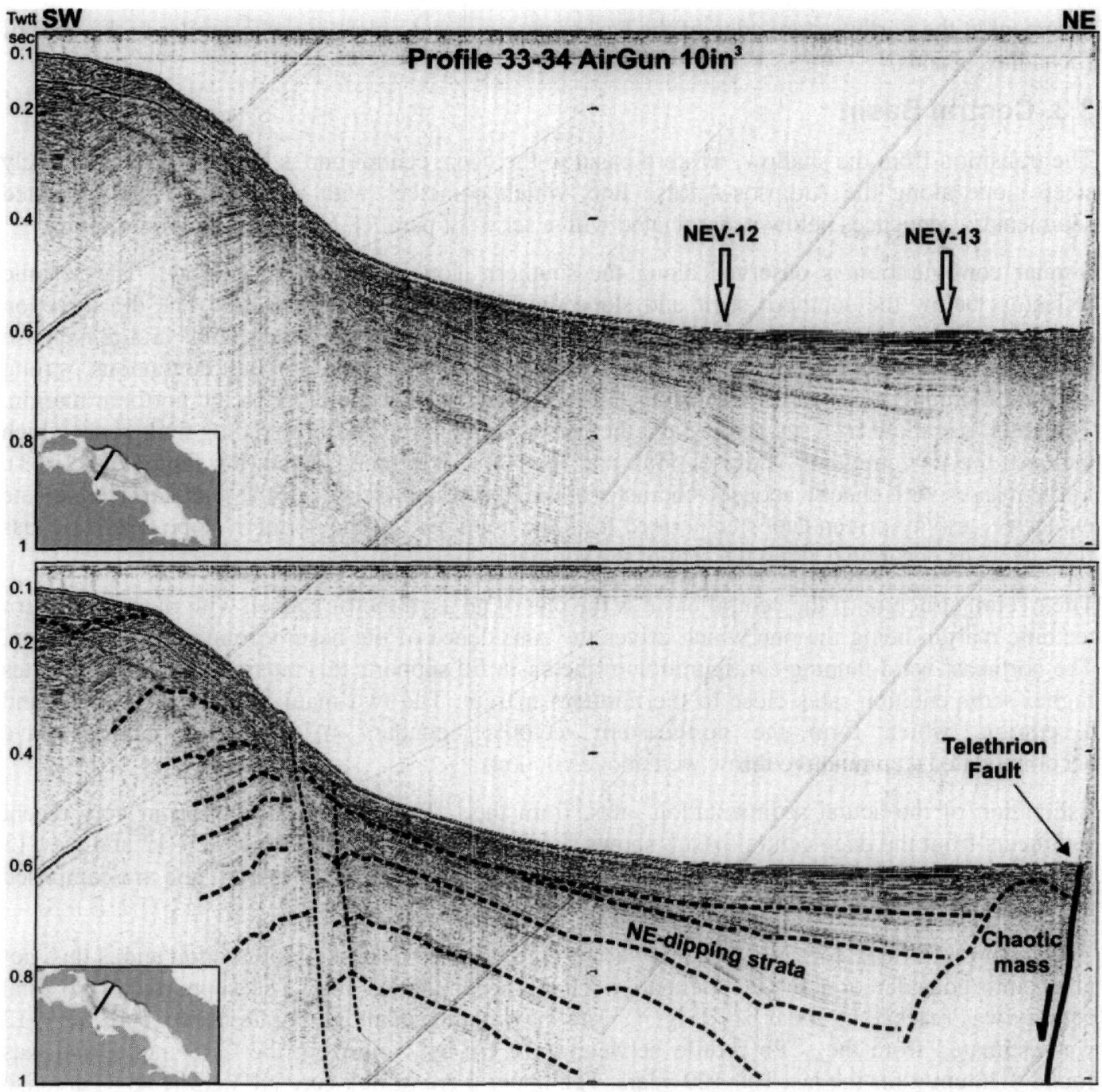

Figure 3 - Air Gun $10 \mathrm{in}^{3}$ single channel seismic profile (up) and interpretation (down). The location of box cores NEV-12 and NEV-13 is shown. The Telethrion Fault is shown as thick black line, arrow indicates sense of movement. Dashed lines mark the trace of the seismic reflectors of the basin fill. Dashed thin lines indicate minor faults at the south slope

Although Melouna fault has little expression on the present seafloor, it seriously affects the basin fill. Three sedimentary sequences are separated by erosional (the lower one) or angular (the upper one) unconformities (Fig. 5). The lower sequence is characterized by rather continuous, strong, curved reflectors, which are being truncated upwards, where they meet the lower unconformity. The latter is being displaced by the Melouna fault by about $80 \mathrm{~m}$ in the profile of Fig. 5 . The total displacement of the roof of the lower sequence is not constant, but varies significantly along the strike of the fault.

The intermediate sedimentary sequence is characterized by continuous reflectors, which onlap the roof of the lower sequence. It is interesting to note that the individual reflectors of both the intermediate and the lower sequences are bended from both sides towards the Melouna fault (Fig. 5). Moreover, the vertical throw of the fault decreases dramatically upwards. Both aforementioned observations, along with the variable cumulative throw along strike, are evidences that strike-slip movement may be a significant component of the, apparently normal, Melouna fault. 


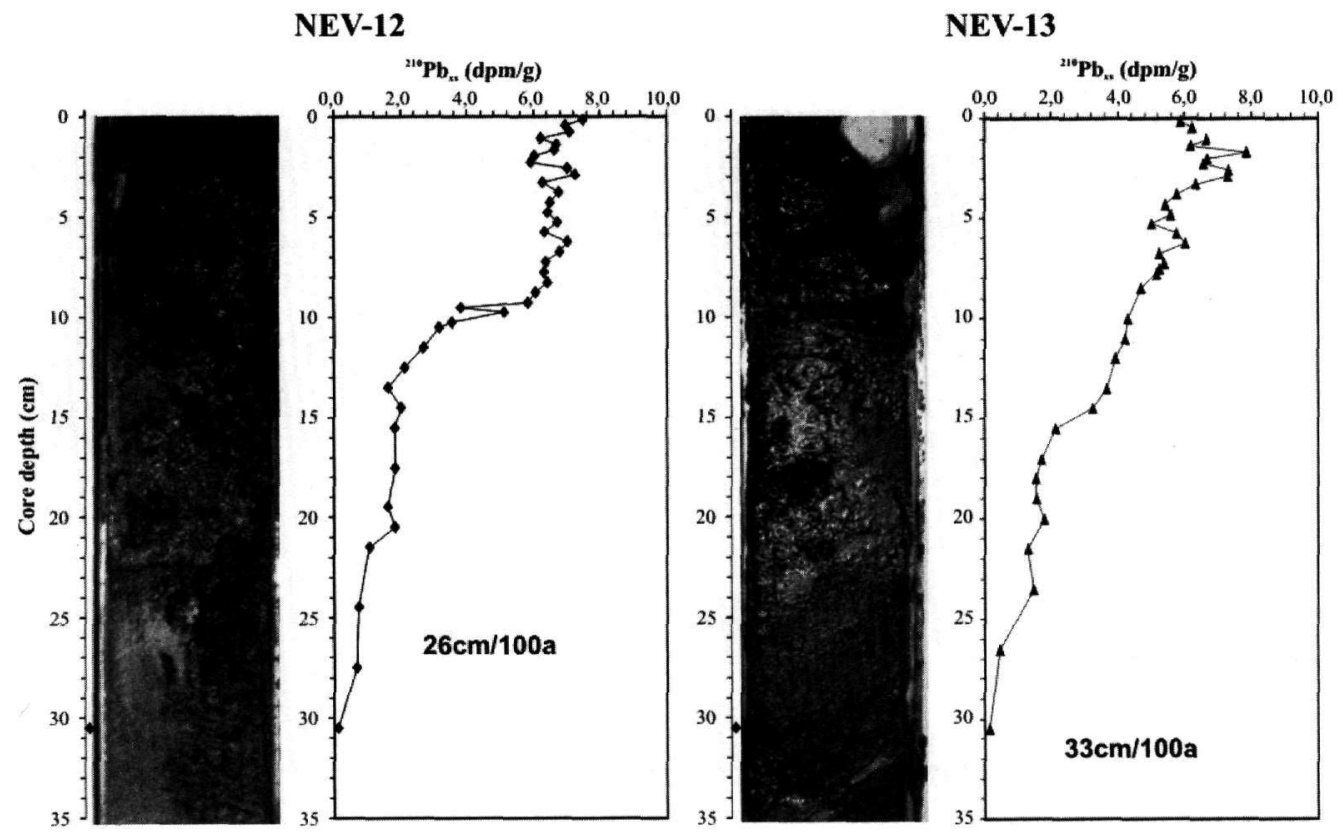

Figure 4 - Photograph of the upper $35 \mathrm{~cm}$ and ${ }^{210} \mathrm{~Pb}$ activity curves of NEV-12 (left) and NEV-13 (right) box cores taken from the deep central basin of the North Evia Gulf. Estimated maximum, actual sedimentation rates are shown. Location of box cores in Fig. 1a, 3

The updoming of the lower sequence along the central axis of the southeastern basin results to the formation of two parallel trending subbasins, which are expressed in the sedimentary pattern of the intermediate sequence.

The southwestern subbasin, hereafter called Malesina subbasin, reaches maximum thickness of about 350 msecs twtt. (about $300 \mathrm{~m}$ ) which is being observed either along the middle axis of the subbasin or close to Melouna fault. The boundary of the Malesina subbasin to the Pliocene sequence of Malesina Peninsula is not well imaged. Although no significant fault has been observed on the seismic profiles, the transition from the depocenter to the uplifted peninsula is rather abrupt. According to the seismic data, some parts of the Malesina subbasin display symmetric character, while in other parts subsidence is enhanced close to the Melouna fault.

The depocenter of the northeastern subbasin, hereafter called Kandili subbasin, with maximum thickness of about 500 msecs twtt (about $400 \mathrm{~m}$ ) lies close to the Kandili fault zone. Similar to the central basin, the individual reflectors of the Kandili subbasin dip northeastwards, toward the Kandili fault zone and they are bended upwards close to the fault surface. The Kandili fault zone forms the tectonic boundary to the alpine basement of North Evia island. The overall configuration of the Kandili subbasin is the one of an asymmetric graben, with the northeastern tectonic margin as the leading role to the subsidence of the subbasin.

No age constrains are available to allow a direct chrono-stratigraphic control of the sedimentary fill of the southeastern basin. Consequently, only assumptions on the possible age of the various sedimentary sequences can be made, on the basis of the existing seismic data and an attempt to correlate the submarine deposits with the post-alpine formations, which outcrop on the adjacent land areas. Thus, we assume that the lower sequence of the southeastern basin may be equivalent to the Pliocene sediments of Malesina Peninsula and North Evia island. If this assumption is true, then a minimum subsidence of $400-500 \mathrm{~m}$ can be deduced for the southeastern basin in respect to the adjacent Pliocene land deposits. 

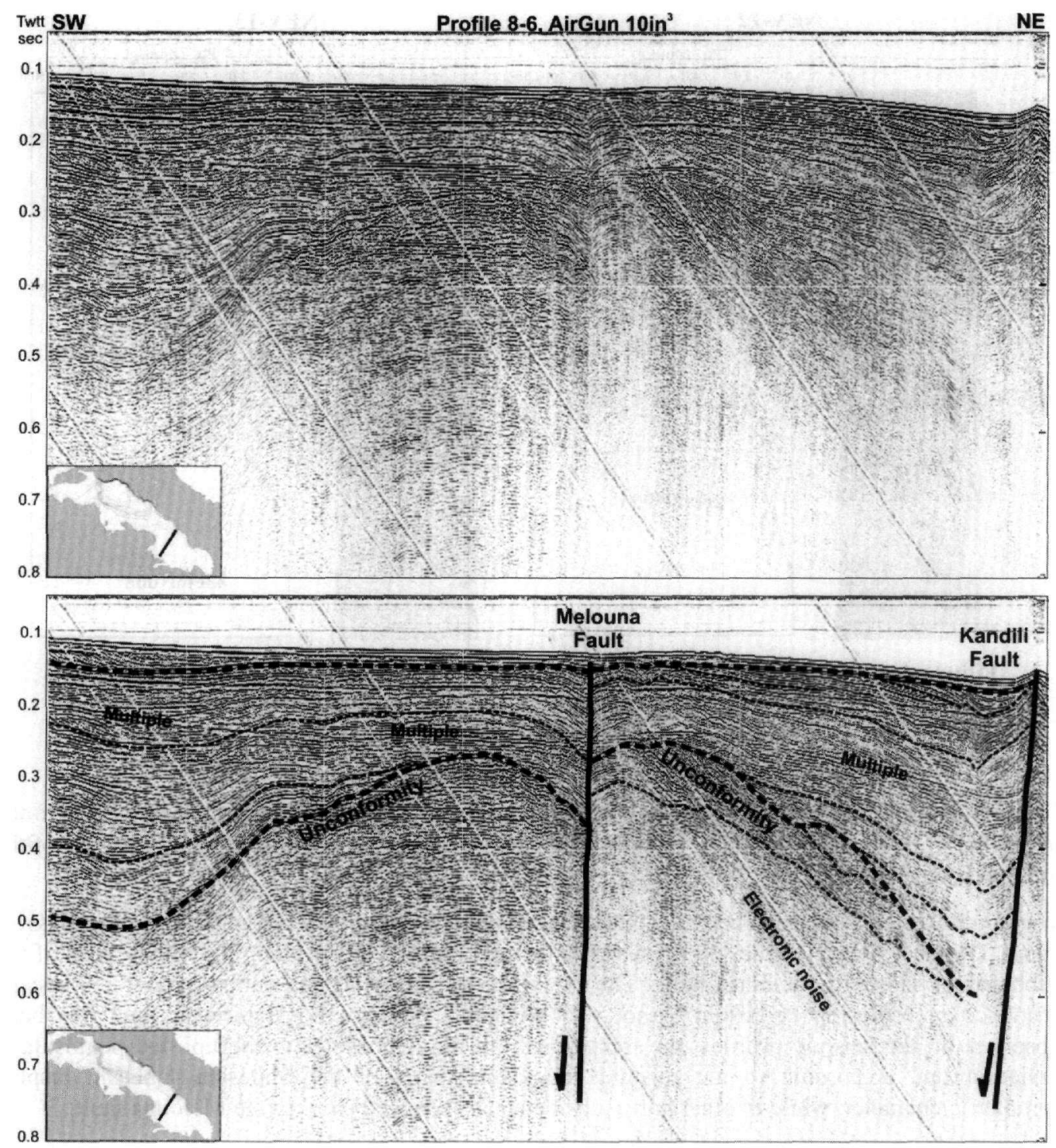

Figure 5 - Air Gun 10in ${ }^{3}$ single channel seismic profile (up) and interpretation (down). Kandili and Melouna Fault are shown as thick black lines, arrows indicate sense of movement. Dashed thick lines mark unconformities. Dashed thin lines emphasize the trace of the seismic reflectors of the intermediate and the lower sequences

Consequently, the intermediate sedimentary sequence may have deposited during a certain period in Quaternary. We have no data to define with higher chronological accuracy the onset of the subsidence of the basin and the sedimentation of the intermediate sedimentary sequence.

Despite the rather shallow depth of the basin and the absence of spectacular fault-controlled slopes, like the ones along the northeastern margin of the central basin, it is quite clear that both main fault zones, Melouna and Kandili, show strong evidence of ongoing activity. Slight deepening of the present seafloor and upward bending of the sediment strata close to the Kandili fault support the above conclusion. Further on, the slight displacement of the present seafloor at the trace of Melouna fault, together with the possible strike-slip component of the fault, are also evidences of ongoing activity. 


\subsection{The North Evia Gulf Pleistocene lake}

The systematic survey of the North Evia Gulf with a high resolution, $3.5 \mathrm{kHz}$ sub-bottom profiler, provided a large amount of data on the Latest Quaternary sedimentary deposits and the recent fluctuations of the water level. The Holocene deposits form a variably thick, transparent drape, which covers the older sediments. Maximum thickness of up to $40 \mathrm{~m}$ has been observed on the southern shelf, off the outflow of torrents, which drain the mountainous areas of mainland Greece (Fig. 2). In the basins the mean Holocene thickness does not exceed a few meters.

Two well developed submarine terraces occur mainly along the southern slope of the central basin, a shallow one at $90 \mathrm{~m}$ and a deeper one at $150 \mathrm{~m}$ depth. Both terraces are caped by the Holocene transparent drape. In several places around the gulf, but especially at the periphery of the southeastern basin, the Holocene drape overlies a seismic package composed of strong, continuous, parallel reflectors. As shown in Fig. 6 the latter overlie a lower transparent horizon and onlap an irregular, high amplitude reflector, which is interpreted as erosional surface. Following the sequence stratigraphic interpretation shown by Lykousis et al. (2006) for similar sequences in the Gulf of Corinth basin, we interpret the upper drape as Holocene deposits and the lower transparent horizon as fine-grain sediments deposited during the previous high sea level stage. Consequently, the intermediate seismic package should represent coarse grain deposits accumulated during the last low sea level stage.

The above described seismic stratigraphy allow drawing some safe conclusions on the water level in the North Evia Gulf during the last glacial stage. The shallowest point where the intermediate seismic package onlaps the erosional surface lies at about $90 \mathrm{~m}(120 \mathrm{msecs})$ below the present sea level and may with good approximation represent the water level during ${ }^{818} \mathrm{O}$ isotopic stage 2. Note that this depth coincides with the one of the shallow terrace, observed mainly along the southern margin of the gulf. Sedimentological description and SEM analysis of samples from many gravity cores has verified the aforementioned interpretation.

The $217 \mathrm{~cm}$ long gravity core NEV-2 was taken from the $150 \mathrm{~m}$ deep terrace at the southern slope of the Gulf. The upper, $206 \mathrm{~cm}$ long, part of the core is dominated by light gray mud/mud turbidites (Fig. 7A). The lower part, between $206-217 \mathrm{~cm}$ bsf, is characterized by alternations of $\mathrm{mm}$ - to $\mathrm{cm}$-thick light gray, olive gray and grayish white mud layers. This pattern was also observed in long cores recovered from the Gulf of Corinth basin (Lykousis et al. 2006) and points out to cyclic changes of redox properties at the water-sediment interface. The transition from the upper to the lower part is marked by gradual increase of the P-wave velocity (from 1520 to 1580 $\mathrm{m} / \mathrm{sec}$ ) and the gamma density, as well as a remarkable decrease of the magnetic susceptibility and the fractional porosity.

Two samples were taken from core NEV-2 and were analyzed under the scanning-electronmicroscope. The marine coccolithophorae Emiliania huxleyi was abundant in the sample taken from the upper part of the core at $196 \mathrm{~cm}$ bsf (Fig. 7B) but was not found in the one taken from the lower part of the core at $212 \mathrm{~cm}$ bsf. Aragonite crystals were observed in the latter sample (lower part of the core) but were absent from the sample taken from the upper part of the core (Fig. 7C). Emiliania huxleyi was also found in samples taken from the same sedimentary sequence of other cores. The above findings allow assuming that the upper part of NEV-2 was deposited under marine conditions while the lower part of the core may have been deposited under lacustrine conditions during the last low water level stand. Van Andel and Perissoratis (2006), on the basis of high resolution data suggested already, that the North Evia Gulf was isolated from the Aegean Sea during the last glacial stage. This assumption is now confirmed. 


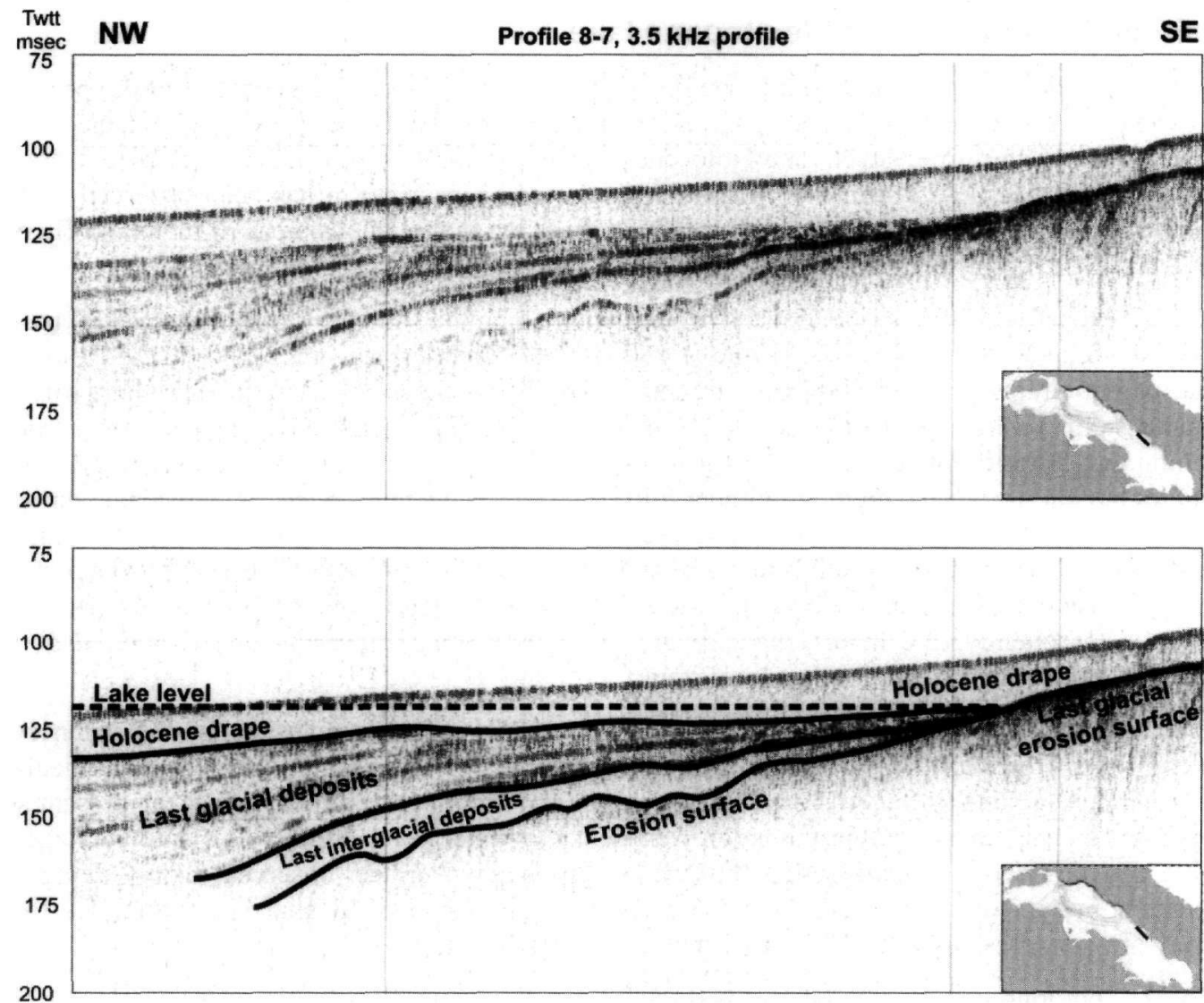

Figure 6 - 3.5kHz subbottom profile (up) and interpretation (down). See text for explanations. Dashed horizontal line indicates last glacial low water (lake) level at about 120 msecs (about $90 \mathrm{~m}$ ) below present sea level
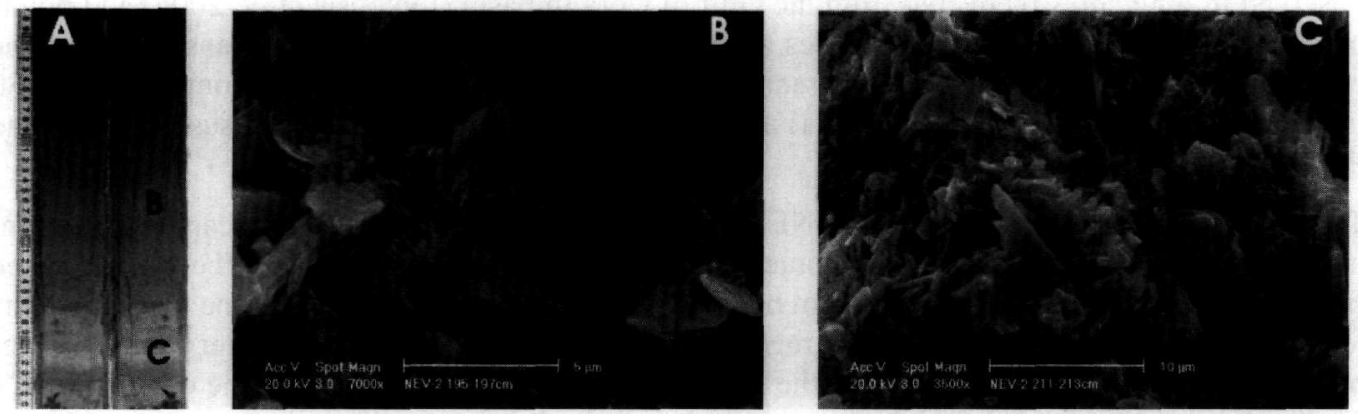

Figure 7 - A) Section of NEV-2 gravity core, between 177-217 cm bsf. B) SEM photograph showing Emiliania huxleyi coccoliths found in sample B from the upper, marine part of the core. C) SEM photograph showing aragonite crystals found in sample $\mathrm{C}$ from the lower, lacustrine part of the core

\section{Conclusions}

The North Evia Gulf can be structurally subdivided into three distinct basins, the western, the central and the southeastern one, with different geological and morphological characteristics. Along axis segmentation may be the result of strain partitioning at the southwestern tip of the 
North Anatolian Fault superimposed on the inherited alpine structure of Central Greece. Main, basin bounding fault zones strike E-W to NW-SE, parallel to the long axis of the basin. Tectonic lineaments perpendicular to that direction, already observed or inferred in the adjacent land masses, were not clearly imaged on the single channel seismic data.

While the evolution of the western shallow basin is controlled by the large faults along its southern margin, the $440 \mathrm{~m}$ deep central basin and the southeastern display northeastward asymmetry, with the Aidipsos, Telethrion and Kandili fault zones, located at the foot of North Evia slope, driving their subsidence.

High resolution subbottom profiles and gravity coring indicate that water level in the North Evia Gulf during the last glacial period was about $90 \mathrm{~m}$ below the present sea level. Since maximum depth of the Lichades island strait does not exceed $65-70 \mathrm{~m}$, an isolated lake should have developed in the place of the present North Evia Gulf. Lacustrine environment in the Gulf during the last glacial period has been verified with the presence of authigenic aragonite crystals in variably colored mud layers underlying Holocene mud deposits.

\section{Acknowledgments}

The authors greatly acknowledge I. Pampidis and P. Mantopoulos, both engineers, for their valuable help in operating geophysical equipment during the cruise. Our thanks go also to the officers and the crew of R/V AEGAEO for their valuable support during the cruises. This survey was conducted in the frame of AMPHITRITE project, funded by the General Secretariat of Research \& Technology, Greece and coordinated by Dr. I. Papoulia at HCMR.

\section{Literature}

Alexandri, M., Nomikou, P., Ballas, D., and Papoulia, I., 2005. Submarine topography and morphological regime of Northern Evoikos basin, Int. Earth. Sci. Coll. Aegean Regions.

Ambraseys, N.N., and Jackson, J.A., 1990. Seismicity and associated strain of central Greece between 1890 and 1988, Geophys. J. Int., 101/3, 663-708.

Armijo, R., Meyer, B., King, G.C.P., Rigo, A., and Papanastassiou, D., 1996. Quarternary evolution of the Corinth rift and its implications for the late cenozoic evolution of the Aegean. Geoph. J. Int., 126, 11-53.

Appleby, P.G., and Oldfield, F., 1978. The calculation of lead-210 dates assuming a constant rate of supply of unsupported ${ }^{210} \mathrm{~Pb}$ to the sediment. Catena, 5, 1-8.

Billiris, H., Paradissis, D., Veis, G., England, P., Featherstone, W., Parsons, B., Cross, P., Rands, P., Rayson, M., Sellers, P., Ashkenazi, V., Daavison, M., Jackson, J., and Ambraseys, N., 1991. Geodetic determination of tectonic deformation in Central Greece from 1900 to 1988 , Nature, 350, 124-129.

Clarke, P.J., Davies, R.R., England, P.C., Parsons, B.E., Billiris, H., Paradissis, D., Veis, G., Denys, P.H., Cross, P.A., Ashkenazi, V., and Bingley, R., 1997. Geodetic estimate of seismic hazard in the Gulf of Korinthos, Geophys. Res. Lett., 24, 1303-1306.

Davies, R.R., England, P.C., Parson, B.E., Billiris, H., Paradissis, D., and Veis, G., 1997. Geodetic strain of Greece in the interval 1892-1992, J. Geophys. Res., 102, 24,571-24,588.

Ganas, A., Roberts, G.P., and Memou, T., 1997. Segment boundaries, the 1894 ruptures and strain patterns along the Atalanti fault, Central Greece, J. Geodynamics, 26/2-4, 461-486.

IGME, 1991. Surficial sediment map of the Aegean sea floor (Pagasitikos sheet), Institute of Geology and Mineral Exploration, Athens. 
Kaberi, H., and Sakellariou, D., 2006. Active sedimentation rates in the northern Evia Gulf and the Alkyonides basin, Comparison using the ${ }^{210} \mathrm{~Pb}$ method. 8th Hell. Oceanography and Fisheries Symposium, Abstracts, 179p.

Kapsimalis, V., Pavlakis, P., Poulos, S.E., Alexandri, S., Tziavos, Ch., Sioulas, A., Filippas, D., and Lykousis, V., 2005. Internal structure and evolution of the Late Quaternary sequence in a shallow embayment: The Amvrakikos Gulf, NW Greece, Mar. Geol. 222-223, 399-418.

Kranis, Ch., 1999. Neotectonic activity of fault zones in central-eastern Sterea Ellas, Lokris, Ph.D. Thesis, Univ. Athens.

Lemeille, F., 1977. Etudes neotectoniques en Grece centrale nord-orientale (Eubee centrale, Attique, Beotie, Locride) et dans les Sporades du Nord (ile de Skiros), These de Troisieme Cycle, Univ. Paris XI-Centre Orsay, 173pp.

Lykousis, V., Sakellariou, D., Moretti, I., and Kaberi, H., 2007. Late Quaternary basin evolution of the Gulf of Corinth: Sequence stratigraphy, sedimentation, fault-slip and subsidence rates, Tectonophysics, in press.

Makris, J., Papoulia, J., Papanikolaou, D., and Stavrakakis, G., 2001. Thinned continental crust below northern Evoikos Gulf, central Greece, detected from deep seismic soundings, Tectonophysics, 341, 225-236.

Mitsopoulos, K., 1895. The great Lokris earthquake of April 1894. National Printing Office, Athens, 40p. (in Greek)

Pantosti, D., De Martini, P.M., Papanastassiou, D., Palyvos, N., Lemeille, F., and Stavrakakis, G., 2001. A reappraisal of the 1894 Atalanti earthquake surface ruptures, Central Greece, Bull. Seism. Soc. America, 91/4, 760-780.

Philippson, A., 1894. Das dies jahrige Erdbeben in Lokris, Zeitschrift Ges. Erdkunde zu Berlin, 21, 332-334. (in German)

Radakovitch, O., 1995. Étude du transfert et du dépôt du matériel particulaire par le ${ }^{210} \mathrm{Po}$ et le ${ }^{210} \mathrm{~Pb}$. Application aux marges continentales du Golfe de Gascogne (NE Atlantique) et du Golfe du Lion (NW Méditerranée), PhD. Thesis, Univ. of Perpignan.

Richter, C.F., 1958. Elementary Seismology, Freeman, San Francisco, 768pp.

Roberts, S., and Jackson, J., 1991. Active normal faulting in Central Greece: an overview. In A.M. Roberts, G. Yielding and B. Freeman (eds.), The Geometry of Normal Faults, Geol. Soc. Sp. Publ. 56, 125-142pp.

Rondoyianni, T., 1984. Etude neotectonique des ravages occidentaux du canal d' Atalanti (Grece Centrale), These de Troissieme Cycle, Univ. Paris-Sud-Centre d'Orsay, 193pp.

Skouphos, T., 1894. Die zwei grossen Erdbeben in Lokris am 8/20 und 15/27 April 1894, Zeitschrift Ges. Erdkunde zu Berlin, 24, 409-474. (in German)

Sanchez-Cabeza, J.A., Masqué, P., and Ani-Ragolta, I., $1998 .{ }^{210} \mathrm{~Pb}$ and ${ }^{210} \mathrm{Po}$ analysis in sediments and soils by microwave acid digestion, Journal of Radioactivity and Nuclear Chemistry, 227/1-2), 19-22.

Van Andel, T.H., and Perissoratis, C., 2006. Late Quaternary depositional history of the North Evvoikos Gulf, Aegean Sea, Greece, Mar. Geol., 232, 157-172. 